\title{
First records of Rhinophoridae (Insecta, Diptera) from North Korea
}

\author{
Agnieszka DraBER-MoŃKO \\ Museum and Institute of Zoology,PAS, Wilcza 64,00-679 Warszawa; e-mail: draber@miz.waw.pl
}

\begin{abstract}
The dipteran family Rhinophoridae is recorded from North Korea for the first time. Acompomintho lobata Villeneuve, 1927 is recorded from the mountains: Chonma-San, Myohyang, Pyongyang, Taesong and from areas surrounding them. Oplisa pollinosa Kugler, 1978 is recorded from the Ryongack Mountains. Some notes on the distribution of $A$. lobata are given. Illustrations of $A$. lobata and $O$. pollinosa females are presented for the first time.
\end{abstract}

Key words: Diptera, Rhinophoridae, North Korea

\section{INTRODUCTION}

The Rhinophoridae are a small family of the Calyptrata section of Diptera, with only about one hundred species known worldwide until recently. Verves \& Khrokalo (2006) recorded 144 species distributed in all zoogeographic regions. Seventy five species are recorded from the Palaearctic region (Herting 1993, Pape \& Kurahashi 1994). The greatest number of species occurs in the Mediterranean basin and in South Africa. Only a few species are known from the Afrotropical humid tropics, and no species have been recorded from Madagascar. Four species are recorded from the Oriental region (Crosskey 1977b). A small number of species occurs in the Neotropical and Australasian regions (Pape 1998). The family Rhinophoridae is distributed worldwide and it was expected to occur in North Korea as well, since Pape \& Kurahashi (1994) had recorded A. lobata from Japan and South Korea. I take this opportunity to present the first North Korean records of this family.

The family Rhinophoridae was extensively reviewed by Crosskey (1977a) who discussed a number of taxonomic characters in detail. The Rhinophoridae were redefined by Pape (1986) on the basis of the apomorphic structure of the aedeagus and this author provided a phylogenetic analysis of the woodlouse flies. Wood (1987) gives a concise summary of the general morphology and biology.

All species of which the biology and the preimaginal stages have been studied are endoparasitoids of terrestial Isopoda (woodlice).

\section{MATERIAL AND METHODS}

The material collected in North Korea by researchers from the Institute of Zoology PAS is fairly small. However, because of poor knowledge of this group of Diptera in Eastern Asia, including Korea, the material was studied. Rhinophorid flies were collected during three expeditions to North Korea: in 1959, 1987 and in 1990. Detailed descriptions of these expeditions are in Mroczkowski (1972) and Bańkowska \& Sterzyńska (1997).

The scanty material of Rhinophoridae includes 16 specimens collected with a sweeping net or using Moericke's yellow traps placed on the grass and in brushwood. The locations of the sampling areas in North Korea are presented in Fig. 1. 


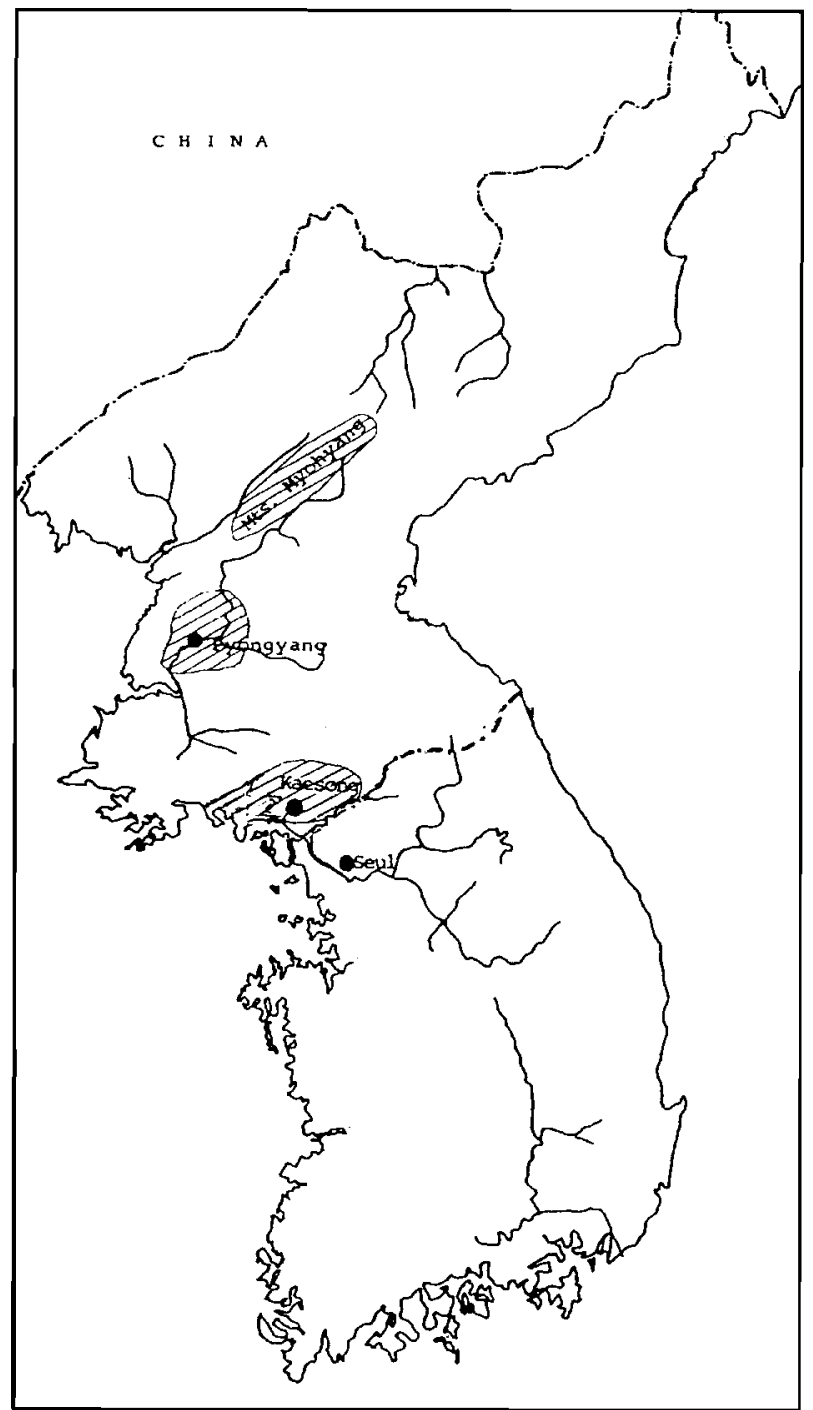

Fig. 1. Location of sampling areas in North Korea in years 1959-1990.

\section{LIST OF SPECIES}

Tribe Azaisiini

Acompomintho Villeneuve, 1927

\section{Acompomintho lobata Villeneuve, 1927}

Reveue Zool. Afr., 15: 223. Type-locality: Tainan, Hokuto, Formosa.

Material examined: North Korea, Myohyang Mts., 15.08.1959, 1 ㅇ, leg. B. Pisarski and J.

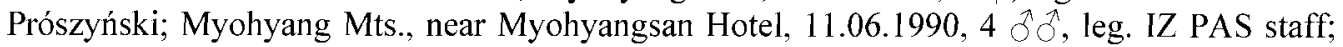
Myohyang Mts., valley of Hyangsan-chon River, 29.08.1987, 1 d, leg. E. Kierych; Tephun 
near Kujang-dong, 5.09.1959, 1 đ, 1 †, leg. B. Pisarski and J. Prószyński; Taesong Mts., Pyongyang, 21.07.1959, 1 q, leg. B. Pisarski and J. Prószyński; the same place, 11.09.1959, 1 q, leg. B. Pisarski; Pyongyang, Taesongsan Park, 6.06.1990, 1 q, leg. B. Pisarski and J. Prószyński; Pyongyang-City, near Michon Lake, 31.08.1987, 1 §ै, leg. E. Kierych; PyongyangCity near tomb of King Tongmen, 27.06.1990, 1 §, leg. IZ PAS staff; Chonma-San Mts., Kaesong near the Zoo Park, 29.06.1990, 2 ठै, leg. IZ PAS staff.

This species was hitherto known only from the extensive type series collected in Taiwan (Formosa) - Oriental Region (Villeneuve 1927, Townsend 1927, 1938 and Lopes 1938), in Riu-Kiu Insel (Japan) and in South Korea (Pape \& Kurahashi 1994). Here it is reported from North Korea. The species has been described by Villeneuve (1927), for redescriptions and further data see Townsend $(1927,1938)$, Lopes (1938) and Herting (1961). The A. lobata male has been illustrated by Lopes (1938), but illustrations of $A$. lobata females (Figs 2-7) are presented here for the first time.

Female. Colour. Frontal vitta redbrown. Fronto-orbital plates and parafacialia silver-white pollinosity. Antenna black with orange proximal pedicel and first flagellomere orange at base. Gena light brown. Palpus light brown-yellow. Postcranial surface shiny black (Figs 2 \& 3). Thorax shiny black with grey-white pollinosity (two stripes) from anterior border of the thorax up to anterior margin of scutellum. Legs black, hind tibia light brown. Wings infuscated (Fig. 7). Basicosta light brown, tegula black. Halter dark brown at base light brown. Upper and lower calypters white. Abdomen shiny black (Figs 5 \& 6).

Head (Figs 2-4). Frons seen from above wider than eye. Frontal vitta wider than frontoorbital plate (Fig. 4). Facial profile receding: vibrissal angle almost in line with anterior margin of eye (Fig. 2 ). Facial ridge bare, but parafacial plate with a row of strong setae close to facial ridge. Frons distinctly shorter than face (Fig. 3). Gena nearly half the large diameter of eye. Postocular setae very strong. Antennal insertion distinctly above eye middle. Antenna long and first flagellomere almost as long as eye height. Arista thickened on at least half its length and with second aristomere twice as long as broad. Wing cell $\mathrm{r} 4+5+\mathrm{m}$ long petiolate and bend of $\mathrm{m}$ forming abrupt right-angle (Fig. 7). Hind tibia with pairs ad, pd and $\mathrm{v}$ setae. Cerci very long and slender.

North Korea is the fourth country from which Acompomintho lobata was recorded.

Distribution: Formosa, Japan, South and North Korea.

Tribe Rhinophorini

Oplisa Rondani, 1862

\section{Oplisa pollinosa Kugler, 1978}

Israel J. Ent., 12: 84. Type locality: Carmel (Israel).

Material examined: North Korea, Ryongack Mts., Daebong near Pyongyang, 7.06.1990, 1 q, leg. IZ PAS staff.

This species was hitherto known only from the extensive type specimens collected in Israel (Kugler 1978). The species was described by Kugler (1978) and the male head was illustrated by him. The present record of $O$. pollinosa Kugler is the second site of this species. The North Korean female of $O$. pollinosa was compared with the type specimen.

No key to species of Oplisa Rondani has been published. Pape \& Kurahashi (1994) presented a taxonomic discussion of the genus Oplisa Rond.

Female. Length $4.5 \mathrm{~mm}$. Thorax with one pair of presutural acrostichal bristles. Wing (Fig. 8 ) with distinctly two costal spines. Node at base of vein $r_{4+5}$ with one very strong seta and with additional fine setula dorsally. Abdomen densely pollinose (Figs $9 \& 10$ ).

Distribution: Israel (Kugler 1978) and North Korea. Species new to Korea. 


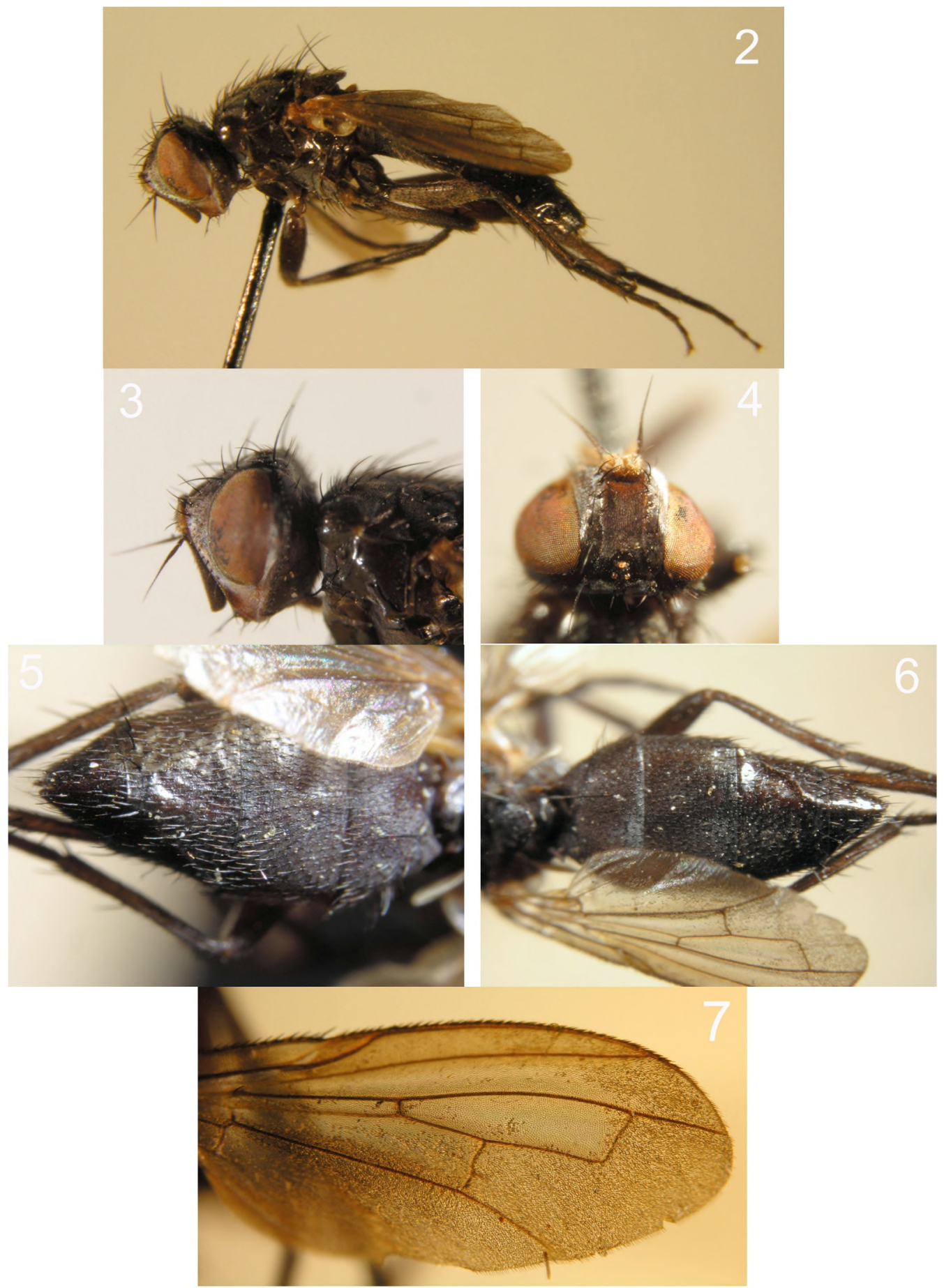

Figs 2-7. Acompomintho lobata Villeneuve, female, North Korea, Taesong Mts., Pyongyang, 11.09.1959, leg. B. Pisarski and J. Prószyński (photo C. Bystrowski); 2 - side-view, 3 - head with antenna, in profile, 4 - head dorsal view, 5 - abdomen, light from above, 6 -abdomen, light from side, 7 -wing. 

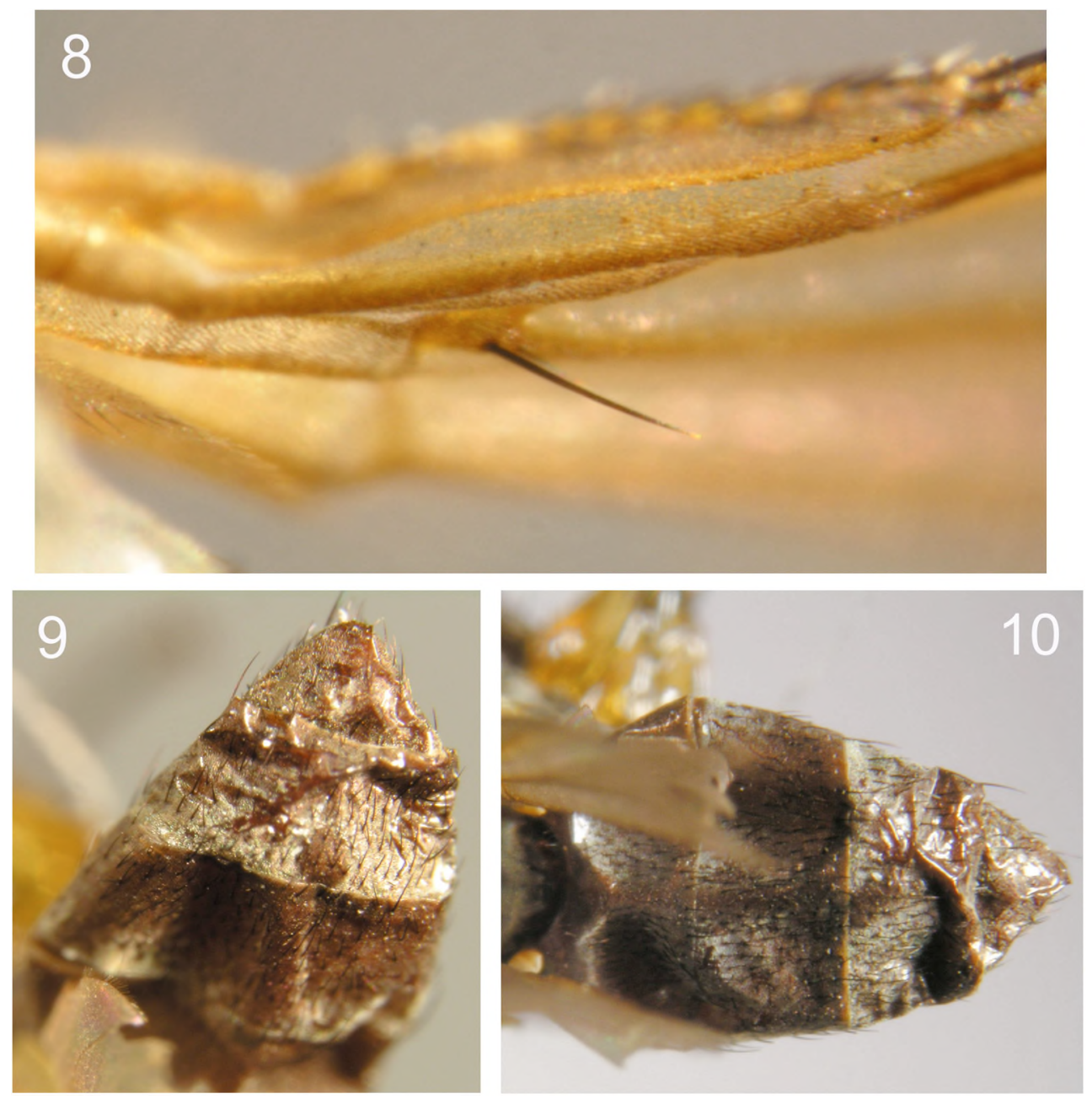

Figs 8-10. Oplisa pollinosa Kugler, female, North Korea, Ryongack Mts. Daebong near Pyongyang, 7.06.1990, leg. IZ PAS staff (photo C. Bystrowski); 8 - wing, basal part, 9 - abdomen, light from above, 10 - abdomen, light from side.

\section{ACKNOWLEDGEMENTS}

I should like to express my most cordial thanks to Dr Cezary Bystrowski for taking the photographs.

\section{REFERENCES}

BAŃKOWSKA R. \& STERZYŃSKA M. 1997. Faunistic investigations conducted in North Korea by researches from the Institute of Zoology Polish Academy of Sciences from 1959 to 1990. Fragmenta Faunistica 40: 247-253.

CRosskey R. W. 1977a. A review of the Rhinophoridae (Diptera), and revision of the Afrotropical species. Bulletin of the British Museum (Natural History) Entomology 36: 1-66.

CRosskey R.W. 1977b. Family Rhinophoridae. In: DELFINADO M. D. \& HARDY D. E. (eds), A Catalogue of the Diptera of the Oriental Region 3: 584-585.

HERTING B. 1961. 64e. Rhinophorinae. In: E. LINDNER (ed.), Die Fliegen der Palaearktischen Region. E. Schweizerbart'sche Verlagsbuchhandlung 9: 1-36.

HeRTING B. 1993. Family Rhinophoridae. In: Soós Á. \& PAPP L. (eds), Catalogue of Palaearctic Diptera, Anthomyiidae - Tachinidae. Hungarian Natural History Museum 13: 102-117. 
KUGLER J. 1978. The Rhinophoridae (Diptera) of Israel. Israel Journal of Entomology 12: 65-106.

LOPES H. DE SOUZA. 1938. Sobre um Rhinophoridae e varios Sarcophagiade da collecção do "Deutsches Entomologisches Institut" em Berlin-Dahlen. Memorias do Instituto Oswaldo Cruz 33: 555-565.

MroczKowsKI M. 1972. Field Investigations in the Democratic People's Republic of Korea by staff members of the Institute of Zoology of the Polish Academy of Sciences. Fragmenta Faunistica 18: 313-343.

PAPE T. 1986. A phylogenetic analysis of the woodlouse-flies (Diptera, Rhinophoridae). Tijdschrift voor Entomologie 129: $15-34$.

PAPE T. 1998. 3.53. Family Rhinophoridae. In: PAPP L. \& DARVAS B. (eds), Contributions to a Manual of Palaearctic Diptera (with special reference to flies of economic importance). Vol. 3. Higher Brachycera; pp. 679-689. Budapest, Science Herald.

PAPE T. \& KURAHASHI H. 1994. First records of Rhinophoridae (Insecta, Diptera) from Japan. Japanese Journal of Entomology 62: 475-481.

TOWNSEND C. H. T. 1927. New muscoid flies in the collection of the Deutsches Entomologisches Institut in Berlin. Entomologische Mitteilungen 16: 277-287.

Townsend C. H. T. 1938. Manual of Myiology. Part 6. Charles Townsend \& Filhos, Itaquaquecetuba (São Paulo), $246 \mathrm{pp}$.

VERves Yu. G. \& KHROKALO L. A. 2006. 31 Otriad Diptera - Dvukrylye. 122. Sem. Rhinophoridae. In: SIDORENKO V. S. (ed.), Opredelitel nasekomykh Dalnego Vostoka Rossii, 6, 4:9-15. Dal'nauka, Vladivostok.

VILLENEUVE J. 1927. Tachinides nouveaux de Formose et du Congo. Revue de Zoologie Africaine 15: $217-224$.

WoOD D. M. 1987. 109. Rhinophoridae. In: MCAlpine J. F., Peterson B. V., Shewell G. E., Teskey H. J., Vockeroth J. R., WoOD D. M. (eds), Manual of Nearctic Diptera, 2, Research Branch, Agriculture Canada, Ottawa, VI+675-1332 pp. Monograph 28: 1187-1191.

\section{STRESZCZENIE}

\section{[Pierwsze doniesienie o muchówkach $\mathrm{z}$ rodziny Rhinophoridae stwierdzonych $\mathrm{w}$ Korei Pólnocnej]}

W pracy przedstawiono material muchówek z rodziny Rhinophoridae, zebrany przez pracowników Instytutu Zoologii PAN w Warszawie, podczas kilku ekspedycji do Korei Północnej w latach 1959-1990. Wyróżniono dwa rzadko spotykane gatunki, oba nie podawane z Korei Północnej. Zamieszczono uzupełniające opisy samic obu gatunków oraz fotografie nieznanych szczegółów morfologicznych. 